\title{
Expression of CIP2A in renal cell carcinomas correlates with tumour invasion, metastasis and patients' survival
}

\author{
J Ren ${ }^{1,2,4}$, W Li ${ }^{3,4}$, L Yan', W Jiao', S Tian', D Li', Y Tang', G Gu', H Liu', and Z Xü, \\ 'Department of Urology, Qilu Hospital, Shandong University, 107\# Wenhua Xi Road, Jinan 2500 I2, PRC; ${ }^{2}$ The key Laboratory of Cardiovascular \\ Remodeling and Function Research, Chinese Ministry of Education and Chinese Ministry of Public Health, Department of Cardiology, Qilu Hospital, \\ Shandong University, I07\# Wenhua Xi Road, Jinan 2500 I2, PRC; ${ }^{3}$ Department of Microbiology/Key Laboratory for Experimental Teratology of Chinese \\ Ministry of Education, School of Medicine, Shandong University, 44\# Wenhua Xi Road, Jinan 2500 I2, PRC
}

BACKGROUND: Cancerous inhibitor of protein phosphatase 2A (CIP2A) drives cellular transformation. The objective of this study was to detect the potential effects of CIP2A in renal cell carcinomas (RCCs).

METHODS: A total of 107 RCC patients were involved in the study. Cancerous inhibitor of protein phosphatase 2A expression was investigated by real-time PCR and immunohistochemistry. In vitro, we examined the expression of CIP2A and c-Myc and tested the migration and invasion capability of $A 498$ and $K R C / Y$ cells with scratch migration assay and Matrigel invasion assay after down-regulating CIP2A expression using siRNA.

RESULTS: Cancerous inhibitor of protein phosphatase 2A was over-expressed in RCC tissues. Clear cell RCC showed an even higherCIP2A expression level than papillary or chromophobe RCC did. The CIP2A immunostaining level was positively correlated with primary tumour stage, lymph node metastasis, distant metastasis, TNM stage and histological grade (all $P<0.05$ ). High-CIP2A expression implied poor survival for patients $(P<0.05)$. Cancerous inhibitor of protein phosphatase $2 A$ depletion by siRNA down-regulated c-Myc expression and attenuated the migration and invasion of RCC cells.

CONCLUSION: Higher-CIP2A expression positively correlates with the aggressive phenotype of RCCs, and predicts poor prognosis for patients. Cancerous inhibitor of protein phosphatase 2A may be a novel target for prevention and treatment of RCC metastasis and recurrence.

British Journal of Cancer (201I) 105, 1905-191I. doi:10.1038/bjc.2011.492 www.bjcancer.com

Published online 10 November 2011

(c) 201 I Cancer Research UK

Keywords: CIP2A; RCC; metastasis; prognosis; survival

Renal cell carcinoma (RCC) is the most common carcinoma of the adult kidney, and its incidence has gradually increased during the last decades (Eble et al, 2004). Resection of the diseased kidney is a standard therapeutic approach for RCC. However, $\sim 30 \%$ of patients develop metastatic disease after surgery (Zisman et al, 2002), and median survival of those patients is only about 13 months (Cohen and McGovern, 2005). The driving factors underlying RCC metastasis remain poorly defined and better understanding of RCC metastasis mechanisms is required for the development of rational strategies for the prevention and treatment of RCC recurrence.

Cancerous inhibitor of protein phosphatase 2A (CIP2A), a cellular protein phosphatase 2A (PP2A) inhibitor, promotes the stability of c-Myc protein by inducing c-Myc serine 62 (S62) phosphorylation and inhibiting its degradation mediated by PP2A (Junttila et al, 2007). Experimentally identified as an oncoprotein, CIP2A contributes to immortalisation and malignant transformation of human cells. Importantly, recent studies show that CIP2A is

\footnotetext{
* Correspondence: Dr H Liu or Dr Z Xu;

E-mail: hainanliu8I5@yahoo.com.cn (HL)

or xuzhonghuamd@yahoo.com.cn (ZX)

${ }^{4}$ These authors contributed equally to this work.

Received 22 August 2011; revised 13 October 2011; accepted 14

October 201 I; published online 10 November 201 I
}

over-expressed in various human malignancies including head and neck squamous cell carcinoma (Junttila et al, 2007), oral squamous cell carcinoma (Basile and Czerninski, 2010), oesophageal squamous cell carcinoma (Qu et al, 2010), colon (Junttila et al, 2007), gastric (Li et al, 2008), breast (Come et al, 2009), prostate (Vaarala et al, 2010), tongue (Bockelman et al, 2011), lung (Dong et al, 2011; Ma et al, 2011), cervical cancer (Liu et al, 2011) and acute myeloid leukaemia (Wang et al, 2011). Cancerous inhibitor of protein phosphatase $2 \mathrm{~A}$ has also been found to be a prognostic factor for patients with gastric cancer (Khanna et al, 2009), earlystage tongue cancer (Bockelman et al, 2011) and non-small cell lung cancer (Dong et al, 2011).

Expression and biological function of CIP2A in RCC has so far not been investigated. In the present study, we determined CIP2A expression in RCC and explored the potential effects of CIP2A on RCC metastasis and patients' survival.

\section{PATIENTS AND METHODS}

\section{Patients and tissue specimens}

One hundred and seven patients with RCC (86 clear cell RCC, 14 papillary RCC and 7 chromophobe RCC) and 6 patients with renal hamartoma were included in the study, which was approved by the local ethics committee. The patients underwent radical nephrectomy at Qilu Hospital, Shandong University, between 2004 
and 2011. None of the patients had received chemotherapy or radiotherapy before surgery. The diagnosis was confirmed by histopathological examination of the specimens. After surgery, tumour specimens, corresponding tumour adjacent renal tissues and normal renal tissues from patients with renal hamartoma were collected and stored in liquid nitrogen until use. Parts of each sample were fixed in formalin, embedded in paraffin and stored in the Department of Pathology, Qilu Hospital. All the patients were staged according to the tumour node metastasis staging system (Eble et al, 2004) and nuclear grade was evaluated on the basis of the Fuhrman criteria (Fuhrman et al, 1982). Clinical data of all the patients were collected from hospitalisation and subsequent records. Detailed information is listed in Table 1. Follow-up of 85 patients was done, and 47 of them were alive at the end of the follow-up.

\section{Cell lines and culture conditions}

Human RCC cell lines A498 (ATCC, Manassas, VA, USA), KRC/Y (kindly provided by Dr D Xu at Karolinska Institute, Sweden) were cultured at $37^{\circ} \mathrm{C}, 5 \% \mathrm{CO}_{2}$ in RPMI 1640 (Invitrogen, Carlsbad, CA, USA) containing $10 \% \mathrm{FBS}$ (Invitrogen), $100 \mathrm{U} \mathrm{ml}^{-1}$ penicillin (Sigma, St Louis, MO, USA) and $100 \mu \mathrm{g} \mathrm{ml}^{-1}$ streptomycin (Sigma).

\section{Small interfering RNA treatment}

The chemically modified siRNA targeting CIP2A and control siRNA were purchased from Invitrogen. The sequence of siRNA

Table 1 Characteristics of patients with RCC and associations between CIP2A expression and clinicopathologic variables

\begin{tabular}{|c|c|c|c|c|}
\hline \multirow[b]{2}{*}{ Variable } & \multirow[b]{2}{*}{ Total } & \multicolumn{2}{|c|}{ CIP2A staining } & \multirow[b]{2}{*}{$P$-value } \\
\hline & & $0-1$ & $2-3$ & \\
\hline \multicolumn{5}{|l|}{ Gender } \\
\hline Male & 79 & 55 & 24 & 0.125 \\
\hline Female & 28 & 15 & 13 & \\
\hline \multicolumn{5}{|c|}{ Age, years (median 55) } \\
\hline$<55$ & 44 & 33 & 11 & 0.082 \\
\hline$\geqslant 55$ & 63 & 37 & 26 & \\
\hline \multicolumn{5}{|l|}{$T$ stage } \\
\hline$T_{1,2}$ & 74 & 58 & 16 & $<0.000 \mid$ \\
\hline $\mathrm{T}_{3,4}$ & 33 & 12 & 21 & \\
\hline \multicolumn{5}{|l|}{$N$ stage } \\
\hline $\mathrm{N}_{0}{ }^{\circ}$ & 93 & 68 & 25 & $<0.0001$ \\
\hline$N_{1,2}$ & 14 & 2 & 12 & \\
\hline \multicolumn{5}{|l|}{ M stage } \\
\hline$M_{0}$ & 96 & 69 & 27 & $<0.000$ । \\
\hline$M_{1}$ & 11 & । & 10 & \\
\hline \multicolumn{5}{|l|}{ TNM stage } \\
\hline $\mid-\|$ & 66 & 58 & 8 & $<0.0001$ \\
\hline III-IV & 41 & 12 & 29 & \\
\hline \multicolumn{5}{|l|}{ Histological grade } \\
\hline $\mathrm{G}_{1,2}$ & 61 & 47 & 14 & 0.004 \\
\hline $\mathrm{G}_{3,4}$ & 46 & 23 & 23 & \\
\hline \multicolumn{5}{|l|}{ Histology type } \\
\hline Clear cell & 86 & 51 & 35 & 0.022 \\
\hline Papillary & 14 & 12 & 2 & \\
\hline Chromophobe & 7 & 7 & 0 & \\
\hline
\end{tabular}

Abbreviations: CIP2A = cancerous inhibitor of protein phosphatase $2 \mathrm{~A} ; \mathrm{RCC}=$ rena cell carcinoma. 0- I: low-CIP2A expression; 2-3: high-CIP2A expression. for CIP2A was 5'-GACAACUGUCAAG UGUACCACUCUU-3'. Cells were transfected with either CIP2A or control siRNA using Lipofectamine 2000 (Invitrogen) according to the manufacturer's instructions.

\section{RNA extraction, reverse transcription PCR and real-time quantitative PCR}

Total RNA was extracted from tissue specimens and cells with different treatment using TRIzol (Invitrogen) according to the manufacturer's instructions. A total of $1 \mu \mathrm{g}$ RNA was used for reverse transcription with M-MLV reverse transcriptase (Fermentas, Burlington, Canada). The PCR primers used in the study were CIP2A: 5'-CCATATGC TCACTCAGATGATGT-3' (forward) and $5^{\prime}$-GTGTATCATCTCCA CAGAGAGTT- $3^{\prime}$ (reverse) and $\beta$-actin: $5^{\prime}$-AGTTGCGTTACACCCTTTCTTG-3' (forward) and $5^{\prime}$-CAC CTTCACCGTTCCAGTTTT-3' (reverse). Quantitative real-time polymerase chain reaction (QPCR) was performed using SYBR Green PCR Master Mix (Applied Biosystems, Foster City, CA, USA) in a 7000 Real-Time PCR System (Applied Biosystems). $\beta$-Actin was used as the reference gene. Ct values of the samples were calculated, and the relative levels of CIP2A mRNA were analysed by the $2^{-\Delta \Delta \mathrm{Ct}}$ method.

\section{Immunohistochemistry}

In all, $5-\mu \mathrm{m}$ paraffin sections were prepared for the experiments. De-pariffinisation was carried out with xylene and rehydrated, and endogenous peroxidase activity was quenched by $3 \%$ hydrogen peroxide in methanol. Antigen retrieval was done by boiling in a microwave oven in $10 \mathrm{~mm}$ citrate buffer ( $\mathrm{pH}$ 6.0). Block non-specific binding was performed with $5 \%$ bovine serum albumin, and the slides were incubated with anti-CIP2A antibody (ab84547, Abcam, Cambridge, UK; 1:150 dilution). After washing, the slides were incubated with horseradish peroxidase-conjugated goat anti-rabbit IgG. Colour was developed with DAB Horseradish Peroxidase Color Development Kit (P0202, Beyotime, Haimen, China).

The slides were scored by two independent pathologists, who were blind to the data of the patients, according to the intensity and percentage of CIP2A staining. Cancerous inhibitor of protein phosphatase $2 \mathrm{~A}$ expression was scored as 0 (negative), 1 (mild, $0-4 \%$ positive cells), 2 (moderate, $5-49 \%$ positive cells) and 3 (strong, $\geqslant 50 \%$ positive cells).

\section{Western blot}

Total cellular protein was extracted with a lysis buffer containing $50 \mathrm{~mm}$ Tris $-\mathrm{HCl}, 150 \mathrm{~mm} \mathrm{NaCl}, 1 \mathrm{~mm}$ PMSF, $1 \mathrm{~mm}$ EDTA, $1 \%$ Triton X-100, 1\% NaTDC, 0.1\% SDS, pH 7.4 (DBI Bioscience, Shanghai, China). Protein concentration was quantified using BCA Protein Quantitative Kit (DBI Bioscience). And then $25 \mu \mathrm{g}$ protein was resolved by SDS-PAGE, and transferred to PVDF membrane (Millipore, Billerica, MA, USA). The PVDF membranes were blocked with $5 \%$ skim milk and then probed with the primary antibody CIP2A (ab61863, Abcam), c-Myc and $\beta$-actin (Santa Cruz Biotechnologies, Santa Cruz, CA, USA). Then, the membranes were incubated with anti-mouse IgG and developed with the enhanced chemiluminescent Kit (DBI Bioscience).

\section{Colony formation assay}

A498 and KRC/Y cells were transfected with control or CIP2A siRNA for $72 \mathrm{~h}$. Then, the cells were planted into six-well plate (300 cells per well) and incubated for 10 days, as described (Li et al, 2010). Plates were stained with Giemsa, and positive colony formation (with $>50$ cells) was counted. 


\section{Scratch migration assay}

A498 and KRC/Y cells were transfected with control or CIP2A siRNA for $24 \mathrm{~h}$. Thereafter, the cells were scratched with the $1000-\mu$ l pipette tips. Plates were washed twice with PBS in order to remove the detached cells, and incubated using the complete growth medium. Wound closure (cells migrating into the scratched empty space) was observed and measured after 24 and $48 \mathrm{~h}$.

\section{Matrigel invasion assay}

Cell invasion was performed at a 24-well Transwell chamber with a pore size of $8 \mu \mathrm{m}$ (Costar, NewYork, NY, USA). The insert was coated with $50 \mu \mathrm{l}$ Matrigel (dilution at 1:2; BD Bioscience, Franklin Lakes, NJ, USA). A498 and $\mathrm{KRC/Y}$ cells were trypsinised after transfection with control or CIP2A siRNA for $72 \mathrm{~h}$ and transferred to the upper Matrigel chamber in $100 \mu \mathrm{l}$ of serum free medium containing $1 \times 10^{5}$ cells and incubated for $24 \mathrm{~h}$. The lower chamber was filled with medium supplemented with $10 \%$ FBS as chemoattractants. The membranes were fixed and stained using $0.1 \%$ crystal violet. The numbers of invaded cells were counted in five randomly selected high-power fields $(\times 400)$ under a microscope.

\section{Statistical analysis}

Real-time PCR data were analysed using the Mann-Whitney test. Associations between CIP2A immunostaining level and clinicopathological parameters were analysed using the $\chi^{2}$-test. The data of migration and invasion were analysed with the Student's $t$-test. Univariate association with survival was evaluated using KaplanMeier curves, and tested by Log-Rank test (SPSS version 16.0 for Mac; SPSS, Inc., Chicago, IL, USA). Multivariate analyses were performed according to Cox proportional hazards regression model. $P$-value $<0.05$ was considered to be statistically significant.

\section{RESULTS}

\section{Expression of CIP2A and clinicopathological variables of RCC patients}

Expression of CIP2A mRNA was first assessed using real-time quantitative PCR in 26 RCC specimens (15 clear cell RCC, 7 papillary RCC and 4 chromophobe RCC), 15 corresponding adjacent tissues and 6 normal renal tissues. Cancerous inhibitor of protein phosphatase $2 \mathrm{~A}$ was expressed at higher levels in RCC tissues $(89.58 \pm 11.81)$ than in matched adjacent tissues $(5.27 \pm$ 0.56 ) and normal renal tissues $(3.67 \pm 0.92)$ (both $P<0.0001$ ). Intriguingly, CIP2A expression in clear cell RCC specimens $(130.67 \pm 11.48)$ was significantly higher than that in papillary RCC (36.14 \pm 7.71$)$ and chromophobe RCC (29.00 \pm 6.06$)$ (Figure 1). The levels of CIP2A mRNA expression in clear cell RCC, papillary RCC and chromophobe RCC were higher than that in normal renal tissues (all $P<0.05$ ) (Figure 1).

We further analysed CIP2A protein level in 107 RCC tissues, 19 tumour adjacent tissues and 6 normal renal tissues using an immunohistochemical approach. Consistent with CIP2A mRNA expression profile, the presence of the CIP2A protein was found in 75 of $107(70 \%)$ of cancer samples, whereas only 6 of $19(32 \%)$ tumour adjacent tissues and 1 of $6(17 \%)$ normal renal tissues exhibited weak or diffuse CIP2A expression $(P<0.0001)$. Cancerous inhibitor of protein phosphatase $2 \mathrm{~A}$ staining was mainly observed in the cytoplasm and occasionally found in the nucleus of tumour cells (Figure 2A-E). Only weak or diffuse CIP2A staining was observed in some renal tubules in normal renal tissues (Figure 2H). Furthermore, the CIP2A staining level significantly correlated with primary tumour stage, lymph node metastasis, distant metastasis, TNM stage and histological grade (all $P<0.05$ ).

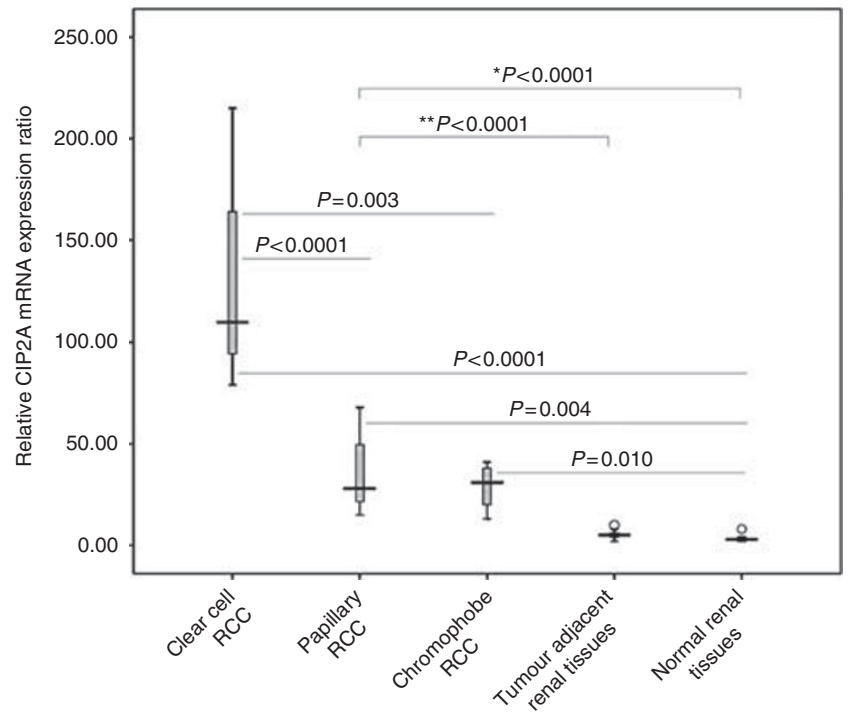

Figure I CIP2A mRNA expression in RCCs and non-neoplastic renal tissues. *RCC specimens vs normal renal tissues. **RCC specimens vs tumour adjacent renal tissues. Clear cell RCC vs papillary RCC $(P<0.000$ I $)$ and clear cell RCC vs chromophobe RCC $(P=0.003)$. Papillary RCC vs chromophobe RCC $(P=0.636)$. Clear cell RCC vs normal $(P<0.000 I)$. Papillary RCC vs normal $(P=0.004)$. Chromophobe RCC vs normal $(P=0.010)$. Tumour adjacent renal tissues vs normal renal tissues $(P=0.107)$. Error bars: the range of each group's data.

There was no significant association between CIP2A expression and patients' gender and age (Table 1).

\section{CIP2A expression and postoperative survival of RCC patients}

Overall survival (OS) was used for survival analysis. Death caused by RCC was appointed as the end point of analysis. Overall survival was defined as the time interval between surgery and death. Univariate 5-year OS revealed that patients with advanced primary tumour stage, lymph nodes metastasis, distant metastasis and high histological grade had worse outcomes (Table 2). The OS rate of patients with high-CIP2A expression (staining intensity: 2-3) was significantly lower than that with low-CIP2A expression (staining intensity: $0-1)(P<0.0001$; Figure $3 \mathrm{~A})$. In addition, multivariate analysis indicated that advanced primary tumour stage, distant metastasis and high-CIP2A expression were independent prognostic factors for RCC patients (Table 3).

Among clear cell RCC patients, univariate and multivariate analysis showed analogous results (Tables 2 and 3). Also, higherCIP2A expression indicated poor prognosis $(P<0.0001$; Figure $3 \mathrm{~B})$ and high-CIP2A expression was a significantly independent prognostic factor for clear cell RCC patients $(P=0.001$; Table 3$)$.

\section{Effects of CIP2A depletion on c-Myc expression, cell migration and invasion in vitro}

Cancerous inhibitor of protein phosphatase 2A mRNA and protein expression was remarkably inhibited in A498 and KRC/Y cells treated with specific siRNA for CIP2A compared with those treated with control siRNA (Figure 4A and B). Furthermore, depletion of CIP2A by siRNA resulted in inhibition of c-Myc protein expression in both A498 and KRC/Y cells (Figure 4B). A498 and KRC/Y renal cancer cells were transfected with CIP2A siRNA and scratched using a Pipette tip $24 \mathrm{~h}$ after transfection. The migration capability of A498 and KRC/Y transfected with CIP2A siRNA was markedly inhibited at $24 \mathrm{~h}$ (A498 control vs CIP2A siRNA: $100 \pm 11$ vs $16 \pm 2$, 

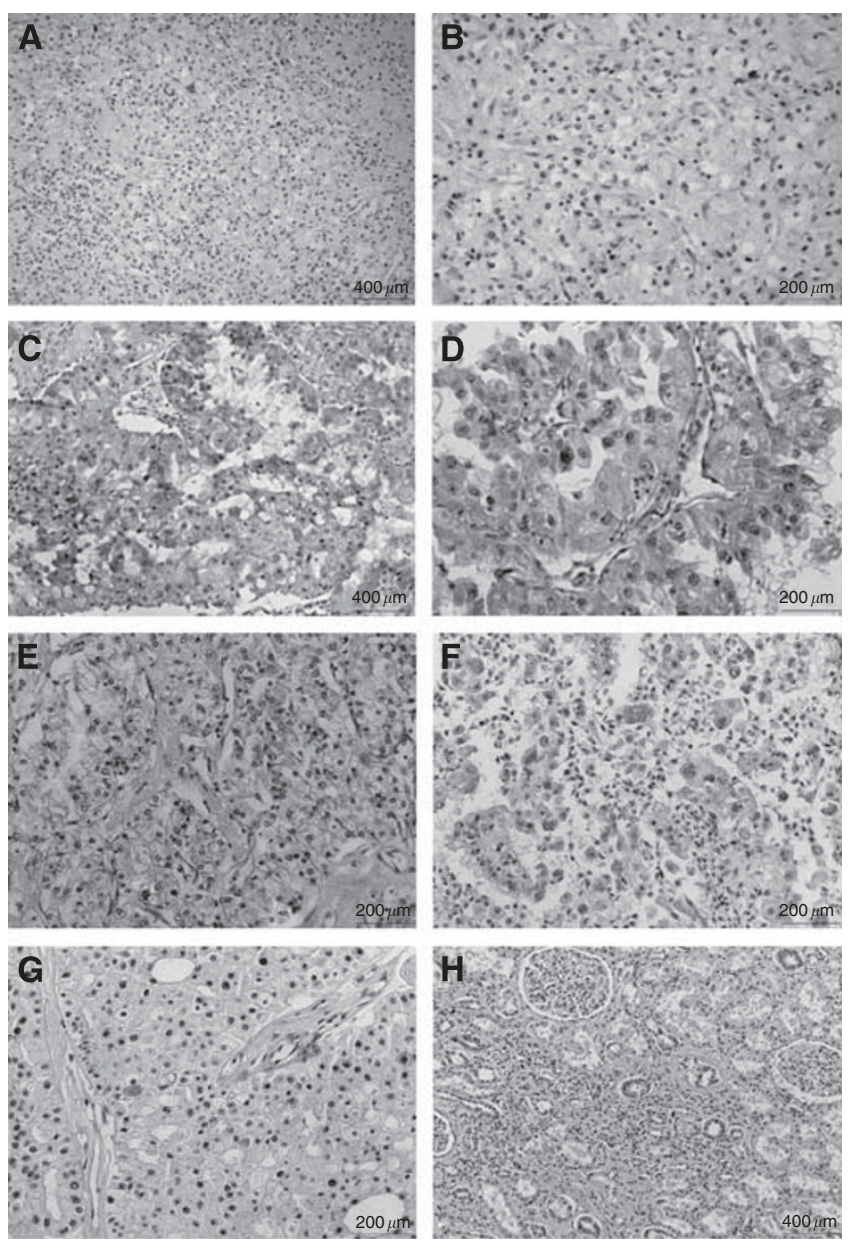

Figure 2 Immunohistochemical staining of CIP2A in RCC specimens and normal renal tissues. CIP2A immunohistochemical staining was performed on different types of RCCs and normal renal tissues, and representative images are shown. (A and $\mathbf{B})$ Weak staining of CIP2A in clear cell RCC (A magnification, $\times$ 100; B: magnification, $\times 200)$. (C and D) Strong staining of CIP2A in clear cell RCC (C: magnification, $\times 100$; D: magnification, $\times$ 200). (E) CIP2A staining in the cytoplasm and nucleus of clear cell RCC (magnification, $\times 200$ ). (F) CIP2A staining in papillary RCC (magnification, $\times$ 200). (G) CIP2A staining in chromophobe RCC (magnification, $\times 200$ ). (H) Extremely weak or diffuse CIP2A staining in renal tubules of normal renal tissues (magnification, $\times 100$ ).

$P<0.0001 ; \mathrm{KRC} / \mathrm{Y}$ control $v s \mathrm{CIP} 2 \mathrm{~A}$ siRNA : $117 \pm 15$ vs $16 \pm 2$, $P<0.0001)$ and $48 \mathrm{~h}(\mathrm{~A} 498$ control $v s \mathrm{CIP} 2 \mathrm{~A}$ siRNA: $235 \pm 5$ vs $28 \pm 3, P<0.0001 ; \mathrm{KRC} / \mathrm{Y}$ control vs CIP2A siRNA: $230 \pm 5$ vs $47 \pm 8, P<0.0001$ ) after scratch (Figure $5 \mathrm{~A}$ and $\mathrm{B}$ ). In addition, Matrigel invasion assay demonstrated that the number of invasive cells passing through the filter were significantly reduced after knocking down of CIP2A in A498 (control vs CIP2A siRNA: $115 \pm 5$ vs $24 \pm 2, P<0.0001$ ) and $\mathrm{KRC} / \mathrm{Y}$ cells (control vs CIP2A siRNA: $71 \pm 4$ vs $12 \pm 3, P<0.0001$ ) (Figure $5 \mathrm{C}$ ).

We further examined whether cell proliferation capacity was altered in cells with transfection of CIP2A siRNA. However, it was found that CIP2A depletion did not have a measurable blocking effect on cell proliferation in colony formation assay (data not shown).

\section{DISCUSSION}

The present study provides the first evidence that CIP2A overexpression widely occurs in RCCs and positively correlates with
Table 2 Univariate 5-year overall survival of RCC patients $(n=85)$

\begin{tabular}{|c|c|c|c|c|c|c|}
\hline \multirow[b]{2}{*}{ Parameters } & \multicolumn{3}{|c|}{$\begin{array}{l}\text { Patients of the } \\
\text { three histological } \\
\text { types }(n=85)\end{array}$} & \multicolumn{3}{|c|}{$\begin{array}{l}\text { Patients of } \\
\text { clear cell RCC } \\
(n=76)\end{array}$} \\
\hline & Total & $\begin{array}{l}\text { 5-Year } \\
\text { overall } \\
\text { survival }\end{array}$ & $P$-value & Total & $\begin{array}{l}\text { 5-Year } \\
\text { overall } \\
\text { survival }\end{array}$ & $P$-value \\
\hline \multicolumn{7}{|l|}{ T stage } \\
\hline $\mathrm{T}_{1,2}^{0}$ & 57 & $73.68 \%$ & $<0.0001$ & 48 & $75.00 \%$ & $<0.0001$ \\
\hline $\mathrm{T}_{3,4}$ & 28 & $17.86 \%$ & & 28 & $17.86 \%$ & \\
\hline \multicolumn{7}{|l|}{$N$ stage } \\
\hline $\mathrm{N}_{0}$ & 72 & $62.50 \%$ & $<0.000$ I & 64 & $60.94 \%$ & 0.001 \\
\hline$N_{1,2}$ & 13 & $15.38 \%$ & & 12 & $16.67 \%$ & \\
\hline \multicolumn{7}{|l|}{ M stage } \\
\hline$M_{0}$ & 76 & $61.84 \%$ & $<0.000$ & 68 & $60.29 \%$ & $<0.000 \mid$ \\
\hline$M_{1}$ & 9 & 0 & & 8 & 0 & \\
\hline \multicolumn{7}{|c|}{ Histological grade } \\
\hline$G_{1,2}$ & 50 & $72.00 \%$ & $<0.0001$ & 47 & $70.21 \%$ & $<0.0001$ \\
\hline $\mathrm{G}_{3,4}$ & 35 & $31.43 \%$ & & 29 & $27.59 \%$ & \\
\hline \multicolumn{7}{|l|}{ CIP2A staining } \\
\hline $0-1$ & 49 & $79.59 \%$ & $<0.0001$ & 42 & $81.00 \%$ & $<0.0001$ \\
\hline $2-3$ & 36 & $22.22 \%$ & & 34 & $20.60 \%$ & \\
\hline
\end{tabular}

Abbreviations: $\mathrm{CIP2A}=$ cancerous inhibitor of protein phosphatase $2 \mathrm{~A} ; \mathrm{RCC}=$ renal cell carcinoma.

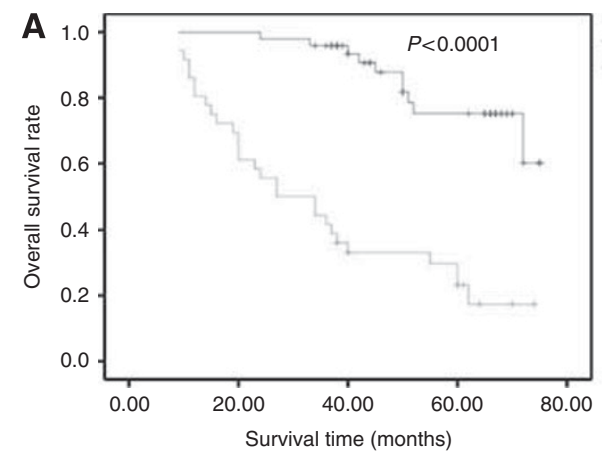

Low-CIP2A expression High-CIP2A expression

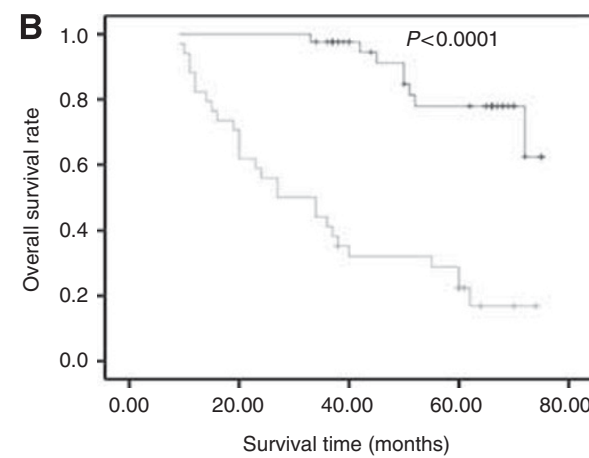

Low-CIP2A expression High-CIP2A expression

Figure 3 Kaplan-Meier curves of OS according to CIP2A expression. Patients with high-CIP2A expression have an overall lower survival rate than patients with low-CIP2A expression. (A) Patients of the three histological types $(n=85)$. (B) Patients of clear cell RCC $(n=76)$ (Log-Rank test, both $P<0.000$ I).

advanced disease stages and metastasis, and negatively affects patients' OS. Consistent with these clinical findings, experiments on RCC cell lines demonstrate that CIP2A depletion significantly 
inhibits migration and invasion of these RCC cells in vitro. Collectively, these results indicate a critical role of CIP2A in driving disease progression and spread of RCCs.

Previous studies have shown that aberrant expression of CIP2A is associated with progressive diseases in a number of other human malignancies including breast (Come et al, 2009), tongue (Bockelman et al, 2011), lung (Dong et al, 2011; Ma et al, 2011), gastric (Li et al, 2008), head and neck cancers (Junttila et al, 2007) and chronic myeloid leukaemia (Lucas et al, 2011). More recently, CIP2A expression has been found to be associated with synovial hyperplasia and invasive function of fibroblast-like synoviocytes in rheumatoid arthritis (Lee et al, 2011). It is currently unclear how CIP2A promotes tumour cell invasion and metastasis. Based on the role of CIP2A in stabilising and up-regulating the MYC oncoprotein, it is likely that MYC is involved in CIP2A-stimulated invasiveness of tumour cells. The MYC oncoprotein is capable of conferring a selective advantage on cancer cells by stimulating proliferation, cell survival, differentiation blockade, genetic instability and angiogenesis, all of which may contribute to metastasis (Baudino et al, 2002; von Rahden et al, 2006; Gordan et al, 2007; Guffei et al, 2007; Vaque et al, 2008). Furthermore, MYC is necessary for the invasion and metastasis of cancer cells in experimental xenografts independent of its effects on proliferation and survival (Wolfer et al, 2010). More recently, MYC has been found to regulate the epithelial-to-mesenchymal transition, a required cellular programme for invasion and migration. MYC

Table 3 Cox regression analysis in predicting the overall survival of RCC patients

\begin{tabular}{|c|c|c|c|c|c|c|}
\hline \multirow[b]{2}{*}{ Risk factors } & \multicolumn{3}{|c|}{$\begin{array}{l}\text { Patients of the } \\
\text { three histologic } \\
\text { types }(n=85)\end{array}$} & \multicolumn{3}{|c|}{$\begin{array}{c}\text { Patients of } \\
\text { clear cell } \\
\text { RCC }(n=76)\end{array}$} \\
\hline & OR & $95 \% \mathrm{Cl}$ & $P$-value & OR & $95 \% \mathrm{Cl}$ & $P$-value \\
\hline \multicolumn{7}{|c|}{ Primary tumour stage } \\
\hline $\begin{array}{l}T_{1,2} \\
T_{3,4}\end{array}$ & 2.788 & $1.277-6.087$ & 0.010 & 3.403 & $1.453-7.967$ & 0.005 \\
\hline \multicolumn{7}{|c|}{ Distant metastasis } \\
\hline $\begin{array}{l}M_{0} \\
M_{1}\end{array}$ & 3.743 & $1.525-9.187$ & 0.004 & 3.066 & $1.226-7.668$ & 0.017 \\
\hline \multicolumn{7}{|c|}{ Histological grade } \\
\hline $\begin{array}{l}G_{1,2} \\
G_{3,4}\end{array}$ & 1.616 & $0.750-3.486$ & 0.220 & 1.028 & $0.454-2.326$ & 0.948 \\
\hline $\begin{array}{l}\text { CIP2A staining } \\
\quad 0-1 \\
2-3\end{array}$ & |.77| & $1.041-3.013$ & 0.004 & 4.607 & $1.884-11.267$ & 0.001 \\
\hline
\end{tabular}

Abbreviations: CIP2A = cancerous inhibitor of protein phosphatase $2 \mathrm{~A}$; OR = odds ratio; $\mathrm{RCC}=$ renal cell carcinoma; $95 \% \mathrm{Cl}=95 \%$ confidence interval. achieves this by stimulating TGF- $\beta$-mediated activation of the SNAIL transcription factor through a microRNA network involving the LIN28B/let-7/HMGA2 pathway (Smith et al, 2009; Viswanathan et al, 2009; Khew-Goodall and Goodall, 2010; Ma et al, 2010; Helland et al, 2011). All these effects of MYC may contribute to tumour cell metastasis driven by CIP2A, and further study is required to elucidate the role of MYC in CIP2A-mediated RCC metastasis.

In some types of tumour cells, CIP2A depletion leads to impaired proliferation potential largely due to diminished MYC expression (Li et al, 2008; Come et al, 2009; Dong et al, 2011). However, neither A498 nor KRC/Y cells exhibited significant alterations in colony formation after CIP2A was knocked down. Clearly, CIP2A inhibition-mediated attenuation of RCC cell invasion is independent of cellular proliferation. This suggests that other factors may be involved in CIP2A promotion of RCC metastasis in addition to MYC.

Cancer metastasis can be one of the key factors affecting patients' survival, but other elements may also lead to poor survival. Recent studies demonstrate that CIP2A displays many other activities, for instance, promoting stem cell self-renewal and giving cancer cells resistance to chemotherapeutic agents (Chen et al, 2010; Kerosuo et al, 2010; Choi et al, 2011). Increased selfrenewal of cancer stem cells and drug resistance may lead to treatment failure, and thereby poor outcomes for patients. Moreover, CIP2A was also implicated in the blockade of cellular senescence and differentiation, as shown in our previous study (Li et al, 2008). Therefore, different mechanisms result in unfavourable prognosis in RCC patients with CIP2A over-expression.

Little is known about the mechanism underlying the aberrant expression of CIP2A in malignant cells. In gastric cancer, Helicobacter pylori infection up-regulates CIP2A expression through the Src and ERK pathways (Zhao et al, 2010). Cancerous inhibitor of protein phosphatase $2 \mathrm{~A}$ is up-regulated by human papillomavirus $16 \mathrm{E} 7$ oncoprotein in cervical cancer (Liu et al, 2011). In addition, CIP2A and MYC form a positive feedback regulation loop to affect each other's expression (Khanna et al, 2009). It is currently unclear what contributes to CIP2A overexpression in RCCs. In the present study, it was found that clear cell RCC exhibited enhanced CIP2A expression at a higher frequency. It is well established that VHL mutation and subsequent HIF $1 / 2 \alpha$ dysregulation play a key part in the pathogenesis of clear cell RCC (Krieg et al, 2000; Krishnamachary et al, 2006); therefore, it may be interesting to probe the effects of these molecular events on CIP2A expression. Also, differences in CIP2A distribution between normal renal tissues and RCC tissues were noticed, and the nuclear accumulation of CIP2A was occasionally seen in RCC tissues. Based on the above observations, dysregulation of CIP2A may occur at different levels in RCCs.

In conclusion, it was found that CIP2A is over-expressed in RCCs especially in clear cell RCC and plays an important role in RCC metastasis. Higher expression of CIP2A positively correlates
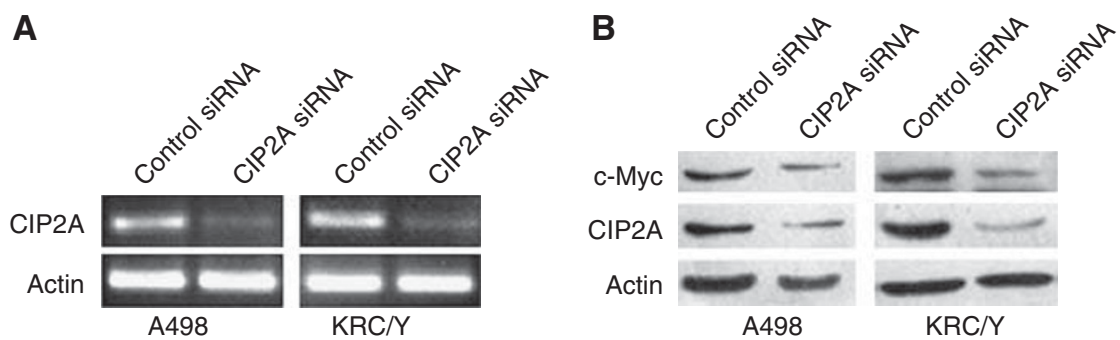

Figure 4 Depletion of CIP2A down-regulates c-Myc protein expression in renal cancer cells. (A) RT-PCR analysis of CIP2A mRNA expression in A498 and $\mathrm{KRC} / \mathrm{Y}$ cells transfected with the specific siRNA targeting CIP2A for $72 \mathrm{~h}$. (B) Western blot analysis of CIP2A and c-Myc protein expression in A498 and $\mathrm{KRC} / \mathrm{Y}$ cells transfected with the CIP2A siRNA for $72 \mathrm{~h}$. Efficient depletion of CIP2A expression was verified. 

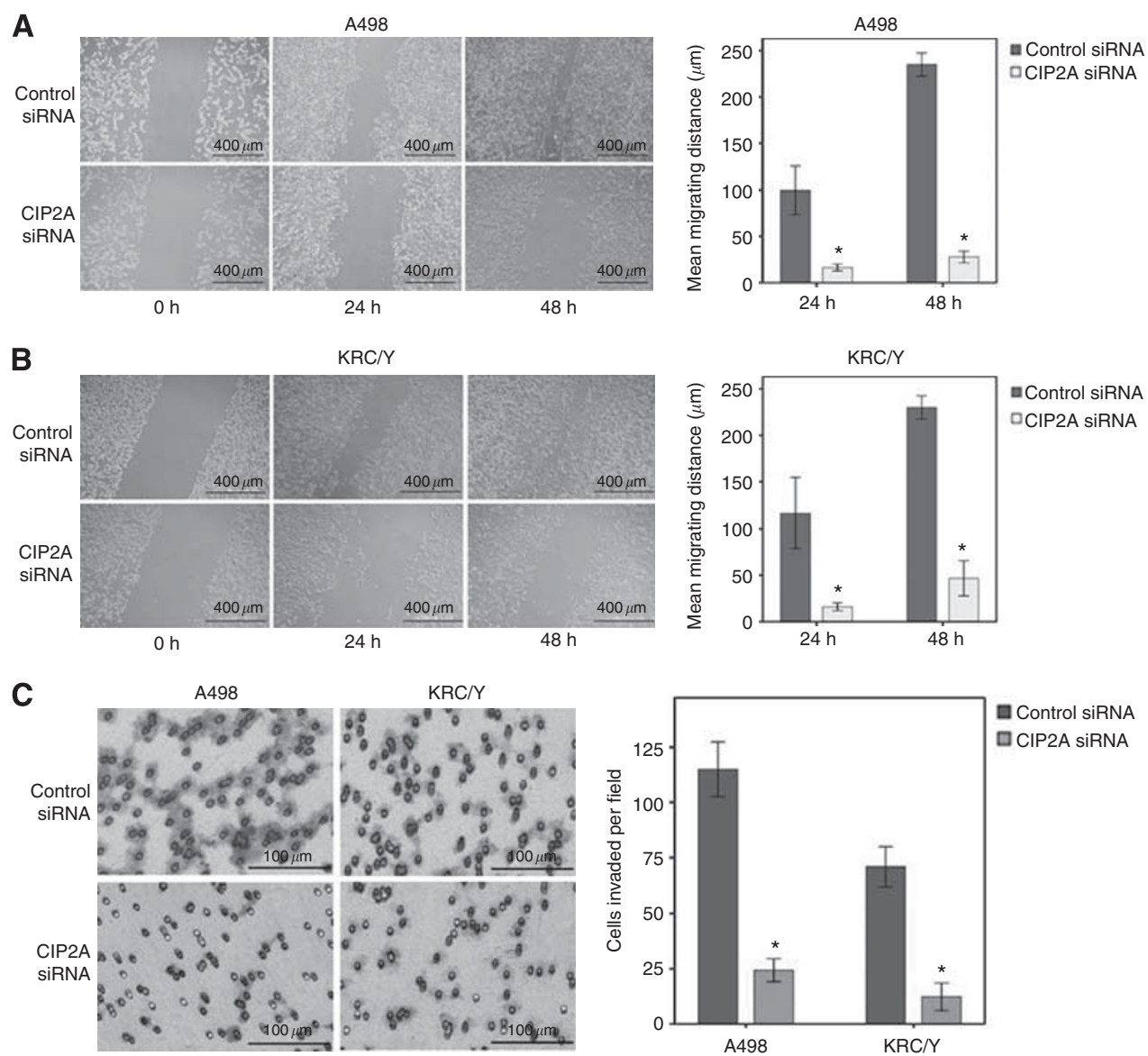

Figure 5 CIP2A depletion attenuated the migration and invasion capability of RCC cells in vitro. (A and $\mathbf{B}$ ) Scratch migration assay of A498 and KRC/Y cells, respectively. The wound closure was measured in photographs at 24 and $48 \mathrm{~h}$. (Left) Representative photographs of scratch migration assay. (Right) Quantification of relative migrating distances of cells with indicated treatment. (C) Matrigel invasion assay of A498 and KRC/Y cells. (Left) Representative images of invading cells treated with indicated siRNA. (Right) Quantification of relative numbers of invading cells representing average counts from five fields of view. Error bars: standard error of the mean (s.e.m.). $* P<0.05$.

with the aggressive phenotype of RCCs, and predicts poor outcome of patients. Therefore, CIP2A may be a novel target for prevention and treatment of RCC metastasis and recurrence.

\section{ACKNOWLEDGEMENTS}

This work was financially supported by the Natural Science Foundation of Shandong (No. 2010ZRE27284), Science and
Technology Development Planning Foundation of Shandong (No. Y2003C10), National Natural Science Foundation of China (No. 81000868), Science Foundation for outstanding young scientists of Shandong Province (No. BS2009SW025) and Science Foundation of Ministry of Education of China (No. 20090131120057). We thank Dr Edward C Mignot, formerly professor of English at Shandong University, for linguistic advice.

\section{REFERENCES}

Basile JR, Czerninski R (2010) The role of CIP2A in oral squamous cell carcinoma. Cancer Biol Ther 10: 700-702

Baudino TA, McKay C, Pendeville-Samain H, Nilsson JA, Maclean KH, White EL, Davis AC, Ihle JN, Cleveland JL (2002) c-Myc is essential for vasculogenesis and angiogenesis during development and tumor progression. Genes Dev 16: 2530-2543

Bockelman C, Hagstrom J, Makinen LK, Keski-Santti H, Hayry V, Lundin J, Atula T, Ristimaki A, Haglund C (2011) High CIP2A immunoreactivity is an independent prognostic indicator in early-stage tongue cancer. Br J Cancer 104: 1890-1895

Chen KF, Liu CY, Lin YC, Yu HC, Liu TH, Hou DR, Chen PJ, Cheng AL (2010) CIP2A mediates effects of bortezomib on phospho-Akt and apoptosis in hepatocellular carcinoma cells. Oncogene 29: $6257-6266$
Choi YA, Park JS, Park MY, Oh KS, Lee MS, Lim JS, Kim KI, Kim KY, Kwon J, Yoon do Y, Moon EY, Yang Y (2011) Increase in CIP2A expression is associated with doxorubicin resistance. FEBS Lett 585: 755-760

Cohen HT, McGovern FJ (2005) Renal-cell carcinoma. N Engl J Med 353: $2477-2490$

Come C, Laine A, Chanrion M, Edgren H, Mattila E, Liu X, Jonkers J, Ivaska J, Isola J, Darbon JM, Kallioniemi O, Thezenas S, Westermarck J (2009) CIP2A is associated with human breast cancer aggressivity. Clin Cancer Res 15: $5092-5100$

Dong QZ, Wang Y, Dong XJ, Li ZX, Tang ZP, Cui QZ, Wang EH (2011) CIP2A is overexpressed in non-small cell lung cancer and correlates with poor prognosis. Ann Surg Oncol 18: 857-865

Eble JN, Sauter G, Epstein JI, Sesterhenn IA (eds) (2004) World Health Organization Classification of Tumors. Pathology and Genetics of Tumors 
of the Urinary Systemandmale Genital Organs. IARC Press: Lyon, pp $12-14$

Fuhrman SA, Lasky LC, Limas C (1982) Prognostic significance of morphologic parameters in renal cell carcinoma. Am J Surg Pathol 6: $655-663$

Gordan JD, Bertout JA, Hu CJ, Diehl JA, Simon MC (2007) HIF-2alpha promotes hypoxic cell proliferation by enhancing c-myc transcriptional activity. Cancer Cell 11: 335-347

Guffei A, Lichtensztejn Z, Goncalves Dos Santos Silva A, Louis SF, Caporali A, Mai S (2007) c-Myc-dependent formation of Robertsonian translocation chromosomes in mouse cells. Neoplasia 9: 578-588

Helland A, Anglesio MS, George J, Cowin PA, Johnstone CN, House CM, Sheppard KE, Etemadmoghadam D, Melnyk N, Rustgi AK, Phillips WA, Johnsen H, Holm R, Kristensen GB, Birrer MJ, Pearson RB, BorresenDale AL, Huntsman DG, deFazio A, Creighton CJ, Smyth GK, Bowtell DD (2011) Deregulation of MYCN, LIN28B and LET7 in a molecular subtype of aggressive high-grade serous ovarian cancers. PLoS One 6: e18064

Junttila MR, Puustinen P, Niemela M, Ahola R, Arnold H, Bottzauw T, Ala-aho R, Nielsen C, Ivaska J, Taya Y, Lu SL, Lin S, Chan EK, Wang XJ, Grenman R, Kast J, Kallunki T, Sears R, Kahari VM, Westermarck J (2007) CIP2A inhibits PP2A in human malignancies. Cell 130: 51-62

Kerosuo L, Fox H, Perala N, Ahlqvist K, Suomalainen A, Westermarck J, Sariola H, Wartiovaara K (2010) CIP2A increases self-renewal and is linked to Myc in neural progenitor cells. Differentiation 80: 68-77

Khanna A, Bockelman C, Hemmes A, Junttila MR, Wiksten JP, Lundin M, Junnila S, Murphy DJ, Evan GI, Haglund C, Westermarck J, Ristimaki A (2009) MYC-dependent regulation and prognostic role of CIP2A in gastric cancer. J Natl Cancer Inst 101: $793-805$

Khew-Goodall Y, Goodall GJ (2010) Myc-modulated miR-9 makes more metastases. Nat Cell Biol 12: 209-211

Krieg M, Haas R, Brauch H, Acker T, Flamme I, Plate KH (2000) Upregulation of hypoxia-inducible factors HIF-1alpha and HIF-2alpha under normoxic conditions in renal carcinoma cells by von HippelLindau tumor suppressor gene loss of function. Oncogene 19: $5435-5443$

Krishnamachary B, Zagzag D, Nagasawa H, Rainey K, Okuyama H, Baek JH, Semenza GL (2006) Hypoxia-inducible factor-1-dependent repression of E-cadherin in von Hippel-Lindau tumor suppressor-null renal cell carcinoma mediated by TCF3, ZFHX1A, and ZFHX1B. Cancer Res 66: $2725-2731$

Lee J, Park EJ, Hwang JW, Oh JM, Kim H, Bae EK, Choi YL, Han J, Ahn JK, Cha HS, Koh EM (2011) CIP2A expression is associated with synovial hyperplasia and invasive function of fibroblast-like synoviocytes in rheumatoid arthritis. Rheumatol Int; e-pub ahead of print 9 April 2011

Li W, Ge Z, Liu C, Liu Z, Bjorkholm M, Jia J, Xu D (2008) CIP2A is overexpressed in gastric cancer and its depletion leads to impaired clonogenicity, senescence, or differentiation of tumor cells. Clin Cancer Res 14: $3722-3728$

Li W, Zeng J, Li Q, Zhao L, Liu T, Bjorkholm M, Jia J, Xu D (2010) Reptin is required for the transcription of telomerase reverse transcriptase and over-expressed in gastric cancer. Mol Cancer 9: 132

Liu J, Wang X, Zhou G, Wang H, Xiang L, Cheng Y, Liu W, Wang Y, Jia J, Zhao W (2011) Cancerous inhibitor of protein phosphatase $2 \mathrm{~A}$ is overexpressed in cervical cancer and upregulated by human papillomavirus 16 E7 oncoprotein. Gynecol Oncol 122: 430-436

Lucas CM, Harris RJ, Giannoudis A, Copland M, Slupsky JR, Clark RE (2011) Cancerous inhibitor of PP2A (CIP2A) at diagnosis of chronic myeloid leukemia is a critical determinant of disease progression. Blood 117: 6660-6668

Ma L, Wen ZS, Liu Z, Hu Z, Ma J, Chen XQ, Liu YQ, Pu JX, Xiao WL, Sun HD, Zhou GB (2011) Overexpression and small molecule-triggered downregulation of CIP2A in lung cancer. PLoS One 6: e20159

Ma L, Young J, Prabhala H, Pan E, Mestdagh P, Muth D, Teruya-Feldstein J, Reinhardt F, Onder TT, Valastyan S, Westermann F, Speleman F, Vandesompele J, Weinberg RA (2010) miR-9, a MYC/MYCN-activated microRNA, regulates E-cadherin and cancer metastasis. Nat Cell Biol 12: 247-256

Qu W, Li W, Wei L, Xing L, Wang X, Yu J (2010) CIP2A is overexpressed in esophageal squamous cell carcinoma. Med Oncol; e-pub ahead of print 8 December 2010; doi 10.1007/s12032-010-9768-9

Smith AP, Verrecchia A, Faga G, Doni M, Perna D, Martinato F, Guccione E, Amati B (2009) A positive role for Myc in TGFbeta-induced Snail transcription and epithelial-to-mesenchymal transition. Oncogene 28: $422-430$

Vaarala MH, Vaisanen MR, Ristimaki A (2010) CIP2A expression is increased in prostate cancer. J Exp Clin Cancer Res 29: 136

Vaque JP, Fernandez-Garcia B, Garcia-Sanz P, Ferrandiz N, Bretones G, Calvo F, Crespo P, Marin MC, Leon J (2008) c-Myc inhibits Ras-mediated differentiation of pheochromocytoma cells by blocking c-Jun upregulation. Mol Cancer Res 6: 325-339

Viswanathan SR, Powers JT, Einhorn W, Hoshida Y, Ng TL, Toffanin S, O'Sullivan M, Lu J, Phillips LA, Lockhart VL, Shah SP, Tanwar PS, Mermel CH, Beroukhim R, Azam M, Teixeira J, Meyerson M, Hughes TP, Llovet JM, Radich J, Mullighan CG, Golub TR, Sorensen PH, Daley GQ (2009) Lin28 promotes transformation and is associated with advanced human malignancies. Nat Genet 41: $843-848$

von Rahden BH, Stein HJ, Puhringer-Oppermann F, Sarbia M (2006) c-myc amplification is frequent in esophageal adenocarcinoma and correlated with the upregulation of VEGF-A expression. Neoplasia 8: $702-707$

Wang J, Li W, Li L, Yu X, Jia J, Chen C (2011) CIP2A is over-expressed in acute myeloid leukaemia and associated with HL60 cells proliferation and differentiation. Int J Lab Hematol 33: 290-298

Wolfer A, Wittner BS, Irimia D, Flavin RJ, Lupien M, Gunawardane RN, Meyer CA, Lightcap ES, Tamayo P, Mesirov JP, Liu XS, Shioda T, Toner M, Loda M, Brown M, Brugge JS, Ramaswamy S (2010) MYC regulation of a 'poor-prognosis' metastatic cancer cell state. Proc Natl Acad Sci USA 107: 3698-3703

Zhao D, Liu Z, Ding J, Li W, Sun Y, Yu H, Zhou Y, Zeng J, Chen C, Jia J (2010) Helicobacter pylori CagA upregulation of CIP2A is dependent on the Src and MEK/ERK pathways. J Med Microbiol 59: 259-265

Zisman A, Pantuck AJ, Wieder J, Chao DH, Dorey F, Said JW, deKernion JB, Figlin RA, Belldegrun AS (2002) Risk group assessment and clinical outcome algorithm to predict the natural history of patients with surgically resected renal cell carcinoma. J Clin Oncol 20: 4559-4566

This work is published under the standard license to publish agreement. After 12 months the work will become freely available and the license terms will switch to a Creative Commons Attribution-NonCommercial-Share Alike 3.0 Unported License. 